\title{
Mineral waters, Spas and Therapeutics in seventeenth and eighteenth centuries Portugal
}

José Pedro Sousa Dias

Museu Nacional de História Natural e da Ciência/Museus da Universidade de Lisboa e Instituto de História Contemporânea

\begin{abstract}
The interest of Portuguese physicians for mineral waters followed a chronological evolution similar to the acceptance of chemical drugs. The the first major medical work on the whole of Portuguese medicinal water resources was the Aquilégio medicinal (1726), by Francisco da Fonseca Henriques. The spa of Caldas da Rainha played an important role in this development. Founded at the end of the fifteenth century, Caldas da Rainha saw its notability newly acknowledged due to the intervention of King John V (1689-1750), who went there with his family and court for thirteen successive years and rebuilt its hospital.

Jacob de Castro Sarmento (1753) was the first of a number of authors who wrote, in the second half of the eighteenth century, about Portuguese mineral waters, reaching its highest point with a synthesis by Francisco Tavares in 1810. The growing interest for the use of medicinal waters went along with the concern about its legitimization, through clinical observation and chemical analysis of its mineral contents. Castro Sarmento was the first to publish the results of such an analysis in 1753, but the communication of analytical results became from that date a common practice in most of the monographs on mineral waters.

In this paper we present a general outline of the growing interest for medicinal waters and spas in Portugal during the eighteenth century, with a special emphasis on the theoretical attitude and practice of the medical community and the ruling classes regarding mineral waters and on the development of the main institutions dedicated to hydrotherapy, trying to interpret the obstacles that prevented a more general social acceptance of spas and a greater adherence of physicians to therapeutic use of mineral waters in Portugal in this period.
\end{abstract}

\section{KEY-WORDS}

Mineral waters; Spas; Hydrotherapy; Chemical analysis; Portugal; 17th-18th centuries

\section{INTRODUCTION}

When writing about therapeutic practice in Portugal at the end of the seventeenth century, the physician João Curvo Semedo included baths amongst the least prescribed treatments given by his colleagues (Semedo 1687: 224). In spite of the fact that the medical use of mineral waters was already starting to gain some acceptance, the usable treatment centers and their resources were still very unsubstantial. In the first half of the century, only three spas, Caldas da Rainha (literally - the Queens Spa), Lafões and Monchique, were widely known and used (Lemos 1991: vol. 1, 45-46).

Despite the permanence of a tradition, not lost during the Middle Ages, of attendance to some spas, the interest of Portuguese physicians for mineral waters followed a chronological evolution similar 
to the acceptance of chemical drugs. The first monograph dedicated to a mineral spring was the Cronografia Medicinal das Caldas de Alafões (1696) by the physician António Pires da Silva, but the first major medical work on the whole of Portuguese medicinal water resources was the Aquilégio medicinal (1726), by Francisco da Fonseca Henriques, physician to King John V, the same that supported João Curvo Semedo in his defence of therapeutics by antimony and other metallic drugs. The inspiration of Fonseca Henriques came both from the therapeutic potential of water as a vehicle for mineral active principles and from the readiness of the King and the court nobility to support hydrological therapeutics. The spa of Caldas da Rainha played an important role in this development. Founded at the end of the fifteenth century by Queen Leonor, wife of John II, Caldas da Rainha saw its notability newly acknowledged due to the intervention of another royal person, King John V (1689-1750), who went there with his family and court for thirteen successive years and rebuilt its hospital.

This interest for Caldas da Rainha attracted the attention of Jacob de Castro Sarmento, who dedicated to this spa his Apêndice ao que se acha escrito na Matéria Médica (1753). Sarmento was the first of a number of authors who wrote, in the second half of the eighteenth century, about portuguese mineral waters, half of which dedicated to Caldas da Rainha, reaching its highest point with the synthesis of Francisco Tavares, Instruções e cautelas práticas sobre a natureza, diferentes espécies em geral, e uso legítimo das águas minerais (1810). The Lisbon Academia Real das Ciências, founded 1779, encouraged the research on hydrological national resources and various monographs on the theme were presented from 1786. The growing interest for the use of medicinal waters went along with the concern about its legitimization, through clinical observation but also through the chemical analysis of its mineral contents. Castro Sarmento was the first to publish the results of the analysis, performed in England, of the waters from Caldas da Rainha (1753), but the communication of analytical results became from that date a common practice in most of the monographs on mineral waters.

This paper aims at understanding the reasons that hinder the widespread social acceptance of spas and the medical use of mineral waters in Portugal during the seventeenth and eighteenth centuries, despite a growing interest for medicinal waters and spas and the existence of a strong royal patronage during the reign of King John VI. At the same time, it intents to define the relationship between the increasing medical acceptance of the use of hydrotherapy and the innovative movement of introduction of chemical concepts and techniques, visible in the Portuguese literature on medicine and therapeutics in the period under study.

\section{Portuguese SPAS.}

Caldas da Rainha was founded in 1485 by the wife of King John II. The town itself, as the name shows, owes its own existence to the spa. The hospital was one of the three large institutions of 
medical assistance built in Portugal at the turn of the fifteenth century, together with the Misericórdia and the Todos-os-Santos Hospital, in Lisbon. The Caldas da Rainha Hospital, to which the Queen gave large subsidies could allocate more than one hundred beds. It had its own wards for men, women, clergy and patients with fevers as well as special rooms for patients of higher social status. It also possessed covered baths for both men and women. The staff were numerous, more than 25 people, including a physician, a surgeon, an apothecary, a barber-bleeder, and male and female nurses(Carvalho 1932: 23-55). The Lafões spa (nowadays São Pedro do Sul) was, together with the previous one, the only to have their own physician during the spa season. Lafões was the oldest in use. The first king of Portugal was treated there in the twelfth century. It possessed a hospital with its own income, but a lot smaller than the one at Caldas da Rainha. Its administration always belonged to members of the nobility, contrarily to what happened at Caldas da Rainha and Monchique, where they were in the hands of the Church. The Monchique spa had been used since the fifteenth century at least. King John II took baths there in 1495, just before his death. The Algarve bishops took upon themselves the construction of houses to cover the baths and accommodate patients since the mid-seventeenth century and administered the hospital since the first half of the next century (Carvalho 1930; Carvalho 1939).

The Portuguese spas mentioned in a 1696 monograph about Lafões only included, besides Caldas da Rainha and Monchique, the ones of Alcafache, Vizela, Chaves and Aregos. These spas were mere covered tanks with no buildings, although in some there could be seen the ruins of old constructions (Silva 1696: 202-204). The spa of Aregos, like those of Lafões and Monchique, was already in use during the Middle Ages. In the twelfth century, Queen Mafalda, wife of King Afonso Henriques had a bathing tank and two-bed lodge built there. Some Luso-Roman spas, like those of Chaves (Aquae Flaviae) and Vizela, were still remembered, but many had already been completely forgotten. The "discovery" of other spas was a process that accelerated during the last decades of the seventeenth century. The spa of Gerez, for example, was only discovered around 1680 (Carvalho 1941). The number of spas and springs referred to in the literature did not stop growing. In 1726, the King's physician was already able to present an impressive list of three dozen spas in use, in addition to two hundred and fifty springs and wells with medicinal properties.

To understand the situation of Portuguese spas we will concentrate our attention mainly on Caldas da Rainha, with some episodic references to Lafões and Monchique. The administration of the Caldas da Rainha Hospital was, since 1530, in the hands of the congregation of Cónegos Seculares de S. João Evangelista. This congregation appointed the administrator (provedor) of the hospital, who was later confirmed by the King. The powers of the provedor were very large. He administered all the Hospital, its income and expenses. He also nominated and dismissed its functionaries and was in charge of patients admission (Carvalho 1932: 65-68; São Paulo 1944: 23-24). His authority over patients is well shown in the reply given by King John IV when the provedor reminded him of his physician advice not to practice violent sports: "Farei o que me advertis, porque neste Hospital 
estou à vossa obediência”" . The Monchique spa was similarly placed under the administration of the Church, more precisely of the bishops of the Algarve, since 1691 (Carvalho 1939: 59-62).

The general procedure for the duration of the season and the use of waters was very similar to the one followed in other European spas. At Caldas da Rainha the season usually started after the middle of April and was over by the end of September (Carvalho 1932: 36). At Lafões the baths started some days after 20th May. They were interrupted during August and restarted until 15th to 20th October (Silva 1696: 165-67). At Monchique, at the end of the seventeenth century, the months designated for the baths were May until September. Around 1780, when the hospital was already in regular use, it was opened at the beginning of July and closed at the end of September (Carvalho 1939: 46 and 69). At Caldas da Rainha, the patients were first examined by the physician, in the presence of the provedor, in order to ascertain if the baths were adequate for their diseases. The provedor based himself on a catalog of diseases proven as curable in order to decide the admission of patients. This rigid system of restricting acceptances was criticized by several authors, as the reason why spa doctors did not know other diseases that could be cured by the waters. The entrance day was dedicated to religious practices. The patients could only start the treatments after confession and communion. Five days were dedicated to syrups and purges. Then the baths commenced, in three series of three baths each, with a resting day in between. Each period of cure lasted a total of 20 days (São Paulo 1944: 237). The bathing timetable was distinct according to each sick ward and patients social status. At Lafões and Monchique the number of baths and of resting days did not follow such rigid rules. In general, all types of baths were practiced at the three spas, but mud baths were little used because they caused a particular repugnance to patients. To drink Caldas da Rainha waters, despite the counsel by Madeira Arrais (Arrais 1642: 207-8), was still faced negatively by the medical staff of the hospital during the first half of the eighteenth century (Carvalho 1932: 165). At Lafões and Monchique the consumption of mineral water was usually advised, but only as part of the diet regime.

Contrarily to what happened at the French spas (Brockliss 1990), the charitable assistance to the poor played a very important role in the Portuguese spas in the seventeenth and eighteenth centuries. At Caldas da Rainha, charitable assistance was in fact the main reason for the existence of the spa. The bylaws (compromisso) of 1512 clearly established the obligation to treat with no charge all the poor patients that came to the hospital, giving them a bed, food, clothes as well as medical care and medicines. The refusal of internment could only be based on medical reasons. This assistance was not only given to poor patients knocking at the hospital door. Since 1627 the Lisbon Misericórdia started sending to the spa dozens of poor patients every year, coming from various hospitals. Their number grew from 28 in 1627 to more than four dozens around 1656. A total of 85 arrived during 1728. At Lafões, the physician and the apothecary had the same obligation of treating the poor patients (Silva 1696: 197). 
At Caldas da Rainha the patients with means of subsistence had to pay for food, medicines, the doctor's fee and the salary of male or female nurses, but they could use the bed and lodging for free. Those that did not stay accommodated at the hospital would need to rent a house and to have someone to prepare their meals and a servant to assist them. The acceptance of a great number of patients paying for the cure brought a large income to the physician and apothecary. Dionísio Fortes, a doctor at Caldas from 1585 until 1627, obtained in 1602 a permission to receive fees from those patients. He lived during the winter in Óbidos and when he departed to Caldas in April he used to say that he was leaving to India. The hospital physician held a position of a certain monopoly, because normally only he cured in the hospital. The only exceptions were the physicians accompanying members of the royal family or of higher nobility.

At the turn of the seventeenth century, only Caldas da Rainha possessed enough staff and acceptable facilities to receive an important number of patients. The hospital had an appreciable number of employees (São Paulo 1944: 22-26 and 210-242). Lafões had a physician, an apothecary, a bleeder and bathing assistants (Silva 1696: 197), but the first physician at Monchique was only to be appointed in 1747 (Carvalho 1939: 46 and 65-66). Lack of accommodation or food were probably the main reasons why patients missed frequently many spas. Caldas da Rainha was the only spa to possess large installations, with distinct wards and cabins for noblemen and ladies of quality, amplified in 1747 by order of King John V. In the remaining spas the available facilities were very much reduced at this time. At Lafões, despite the efforts of Pires da Silva to show that the accommodation was much better than its reputation, it was necessary to empty and use the municipality seat to install patients during the season (Silva 1696: 196-190). Monchique spa had just two houses for the baths (Carvalho 1932: 33 and 62-68). 


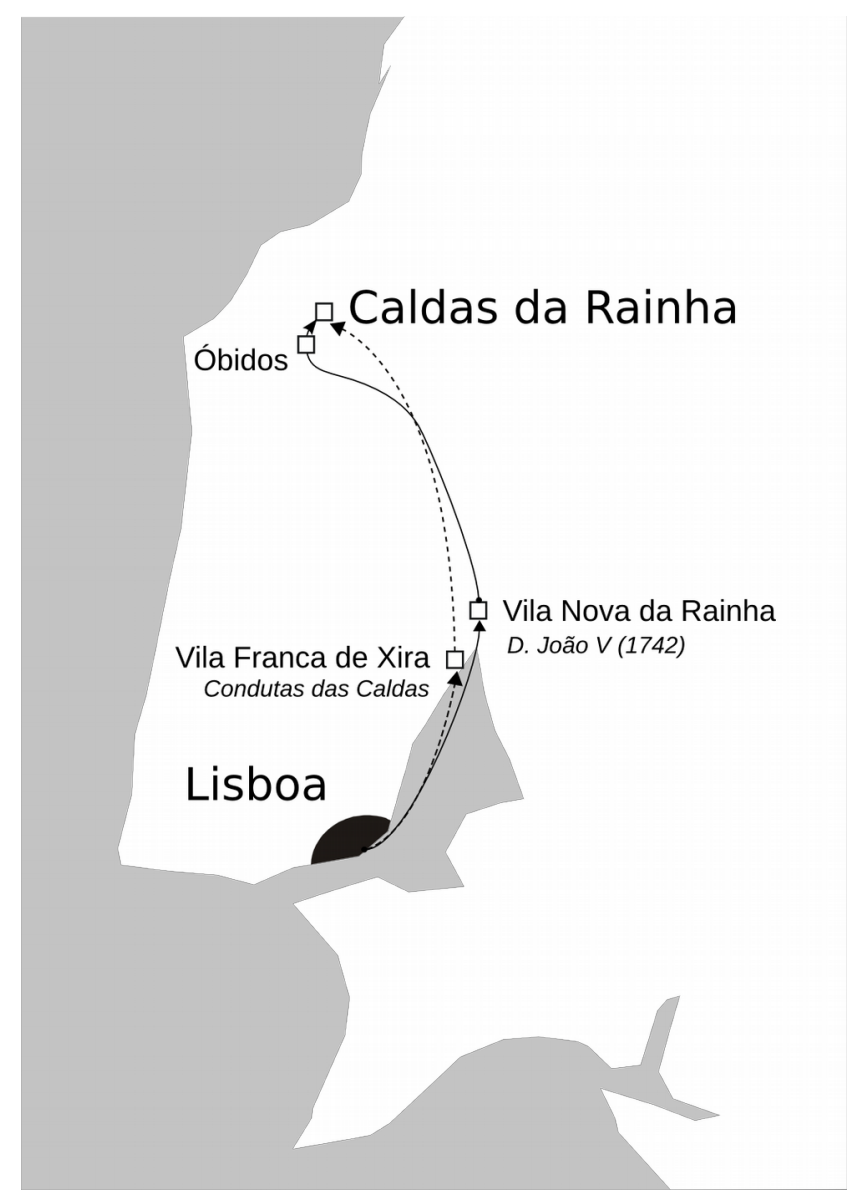

Figure 1: From Lisbon to Caldas da Rainha.
Nearly all of the monarchs of the Bragança Dynasty frequented Caldas da Rainha since the restoration of independence in 1640 . King John IV took thirteen baths in 1645, returning in 1652. His son the Infant D. Afonso bathed as well at Caldas in 1648, when he was very young, and returned there in 1660. Many other members of the royal family were treated at Caldas. Of all of them it was King John V that most honored the spa with his presence, coming to bathe at least thirteen times from 1742 until 1748. In the first of his dislocations he was accompanied by all the royal family and part of the Court. On the return, 17 boats were required for transport (Carvalho 1932: 92-93, 109, 139-151). The favoritism of monarchs for Caldas da Rainha was a natural consequence of its fame, better accessibility and superior accommodations. Besides its healing repute the spa developed since the sixteenth century a reputation of immunity to the various waves of pestilence that swept the country (Carvalho 1932: 56-57, 70, 73-74). Caldas da Rainha was the spa nearest to the Court. Leaving early from Lisbon it was possible to arrive on the same day. With adequate transport the journey included a four hour boat travel plus an eight hours land voyage. Despite the short distance between Lisbon and Caldas the communication routes were not the best. When King John V traveled there for the first time in 1742, it was necessary to enlarge and repair the roads and ways.

Certainly the patients that hastened to the spas, even Caldas da Rainha, were attracted by the waters fame and by the fact that the King and members of the royal family visited them. They were not looking for a pleasant stay in the countryside. The atmosphere and habits at Caldas da Rainha were certainly not propitious to that. It was not only the nuns that found themselves subjected to the most rigorous reclusion at the hospital. The same happened with the secular female patients. No man, religious or layman, even relatives, could enter the women's ward. The enjoyments were minimal and some, such as hunting and ball games, were even strongly discouraged as being harmful to the treatment process. In this way, entertainment were reduced to table games, chats in the hospital grounds and nearby farms and promenades in the surroundings. 


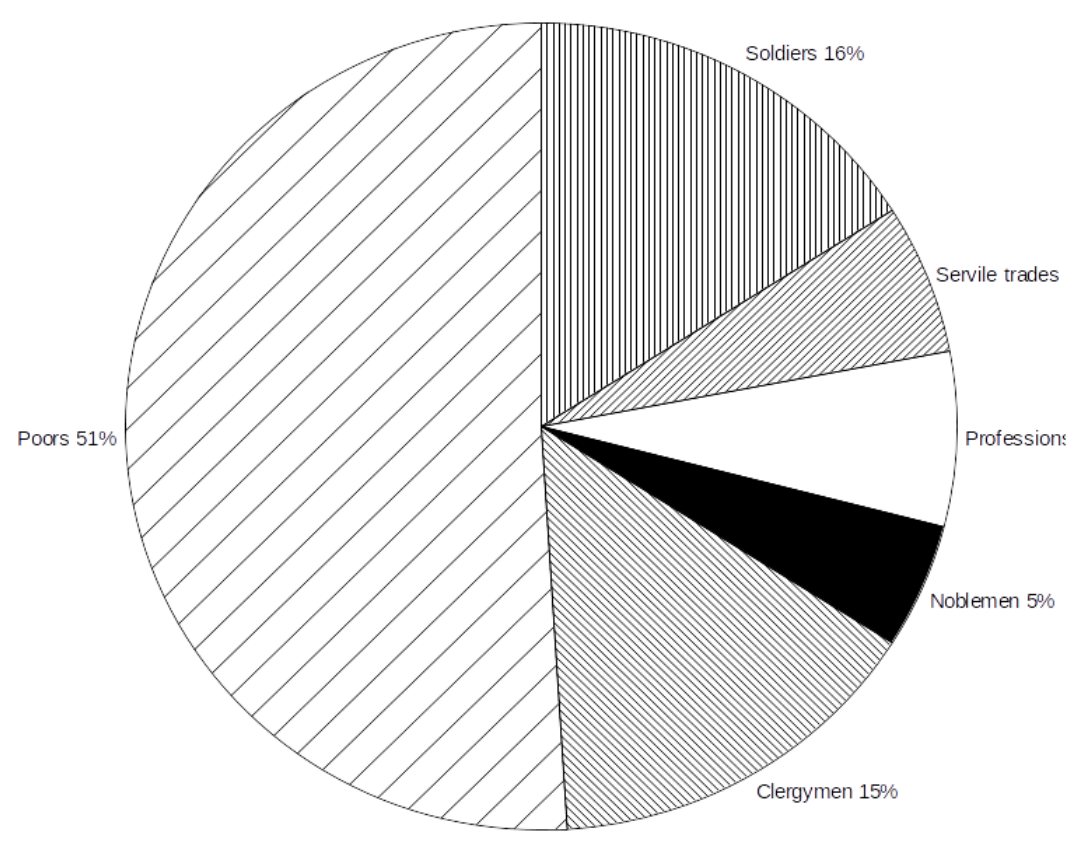

Figure 2: Social status of patients. (Caldas da Rainha, 1654).

We know, thanks to provedor Jorge de São Paulo, the social distribution of the 1046 patients that were treated at Caldas da Rainha in 1654 . $70 \%$ of the patients were cured at the hospital expenses, 21\% paid for their treatment and 9\% were people from the neighborhoods taking their baths furtively. Patients cured gratuitously included soldiers, the most part of clergy members and 484 patients that were simply poor. Considering only those that were fully registered, we see that $15 \%$ of the patients were clergymen and members of monastic orders and 5\% were noblemen. Noblemen occupying private cabins and members of the clergy had their own separate hours for baths and did not mix with the rest of the patients. Literate people, captains of the militia, foreigners, knights of the Ordem de Cristo and members of professions, like doctors and lawyers, constituted $7 \%$ of patients. These were accommodated outside the hospital. Their hours of bathing, from $5 \mathrm{am}$ until 10am, coincided with the noblemen lodged at private houses. Merchants, members of servile trades, servants and slaves made up 6\%. They were interned in the wards at their own cost and took baths at the same time as the poor, from 2am until 4am. As long as the noblemen could be interned in special rooms, paying only for food and health care, members of the ennobling strata, that could not allow themselves to mix with the poor in the wards, had to pay for lodgings outside the hospital. Members of the servile trades, on the other hand, had no alternative but to sleep and take baths in the middle of a crowd of miserables. Certainly this situation, however favorable to the poor and to the members of the clergy and the nobility, did not favor the visits to the spas by the rest of the population strata. 


\section{THE LITERATURE ABOUT MINERAL WATERS AND SPAS (1642-1753)}

The development of the literature about mineral waters was conditioned by the functioning and evolution of the spas. Their eminently charitable character and dominance by members of the clergy or the nobility constituted a brake to the development of the spas. In spite of the existence of a well established spa at Caldas da Rainha since the end of the sixteenth century, the studies on Portuguese springs during this period were not only scarce but also too dependent upon occasional royal interest on the subject, rather than resulting from a vitality of the spas or from a general interest on hydrotherapy. The interest of Portuguese physicians in mineral waters followed a course similar to the adoption of chemical medicines (Dias 2007). As happened with these, the process of vulgarization of spas acquired a new impetus during the second half of the seventeenth century and consolidated itself at the beginning of the next century. In the same way, many of the authors that played a prominent role in the diffusion of hydrotherapy also distinguished themselves as supporters of chemical therapy. Duarte Madeira Arrais (?-1652), physician of the King John IV, initiated the interest of Portuguese physicians in national hydrological resources with the introduction of a small chapter about the usage of spas in the treatment of syphilis, in Método de conhecer e curar o morbo gálico/Method of knowing and healing the French disease (Duarte Madeira Arrais, 1642). In this work, Arrais supported the idea that hot springs, like those of Lafões, Caldas da Rainha and all sulfurous springs, were adequate in the treatment of this disease, if complemented with the administration of medicines like sarsaparilla or guaiac. On the other hand, cold baths, namely from ferrous sources and metallic ones, would be harmful for patients with syphilis (Arrais 1642: 208-210). Madeira was equally one of the first Portuguese physicians to show some interest, however diffident, for pharmaceutical chemistry, resulting from the good reception that the King displayed for chemical medicines. Madeira Arrais was a supporter of the use of antimony and other chemical drugs. By order of King John IV, he wrote in 1648 an essay on the oil of sulphur, after this medicine had cured the Infant D. Afonso.

The first book dedicated to a spa was the Cronografia Medicinal das Caldas de Alafões/Medicinal timeline of Caldas de Alafões (António Pires da Silva, 1696). The author, who had practiced there as a physician, described the qualities and virtues of the Lafões waters according entirely to the Galenic theory. In his opinion these would be hot and dry in the third degree resulting from the presence of sulfur and saltpeter (Silva 1696: 124). The same Galenic point of view would be followed at the conservative University of Coimbra. Manuel Freire, professor from 1667 to 1691, proclaimed the virtues of the Caldas da Rainha and São Pedro do Sul spas (Silva 1696: 130). Manuel Mendes de Sousa Trovão, professor in Coimbra from 1678 to 1704, tried to write a treaty De balneis, for which he asked the physician António Teixeira for information about Caldas de Monchique (Carvalho 1939: 31-47). Around this time, this same António Teixeira (?-1716) wrote an unpublished monograph about the spa of Monchique. The manuscript entitled "Notícia Breve com algumas observações das agoas ou Caldas de Monchique” was published by A. Silva Carvalho 
(Carvalho 1939: 31-47). Teixeira, living in Lagoa, near Monchique, was one of the few Portuguese physicians to openly manifest his support for the defense of chemical medicines undertaken with the publication of Polianteia medicinal/Medical anthology (João Curvo Semedo, 1697). So, it is not strange how he emphasized that the waters virtues were not owed to their temperature but to the minerals they contain. The first medical work dedicated to the whole of Portuguese hydrological resources was the Aquilégio medicinal/Medical reservoir (Francisco da Fonseca Henriques, 1726) Henriques (1665-1731) was a physician of King John V and a supporter of Curvo Semedo in the use of chemical medicines. Fonseca Henriques, like Curvo Semedo, was not an Iatrochemist but a Galenist who used chemical medicines. Several times he wrote that he did not understand why the Galenists and the Chemists fought each others when they should be united. Though he had a great interest in Chemistry, he completely ignored it in his book. Furthermore, he ignores all theoretical considerations. The Aquilégio medicinal is essentially a practical guide. The attempts to explain the the waters virtues are minimal or totally non-existent. In general, Fonseca Henriques limits himself to point the virtues which are normally attributed to them without any additional commentaries. For those who wanted to know more about the spas, Henriques advised them to read authors like Andrea Bacci (1524-1600). The contribution of Fonseca Henriques is appreciable in regard to the minimum information available from previous sources. It included an inventory of a great number of spas and mineral waters. The Aquilégio deals with 30 spas that were being used, 18 hot water springs from which spas could be used and 220 fountains and 28 cold water wells with medicinal properties. It also refers to the properties of various rivers, lakes and reservoirs.

As we have seen, the use of mineral waters occupies a particular place within the eclectic attitude dominant amongst Portuguese physicians of the Baroque, allowing a complete agreement between traditionalist Galenists and sympathizers, more or less doubtful and ill-informed, of chemical doctrine. For the traditionalists, despite the fact that Galen had written very little about baths, hydrotherapy integrated itself easily into the humoral theory. For those interested in Chemistry, waters were a privileged vehicle for the transportation of minerals from the depths of the earth to the body of patients. At times, both these perspectives came to be defended by the same author. Speaking of the spas and their virtues, Madeira Arrais declared that all the doctrine he outlined had been taken from Galen and Hippocrates, little after having declared that all mineral waters possessed the virtues of sulfur and quicksilver, because, in the common opinion of chemists, all of the subterranean metals had been "generated by sulfur, as the father, and by mercury, as the mother" (Arrais 1642: 204 and 206).

The physician Jacob de Castro Sarmento (1691-1762) was the initiator of a turnaround in the Portuguese literature about mineral waters. Despite being an emigrant in England, he always maintained strong ties with his birth country, particularly since 1730, when he multiplied the contacts with Portuguese rulers and colleagues and initiated the edition of numerous medical works in Portuguese language. Being an adherent to a later form of Iatromechanics, and strongly 
influenced by Boerhaave, Sarmento brought a fresh approach to the Portuguese medical literature, one influenced by Newtonian physics and all the intellectual environment that he found when he arrived in England in 1721. His most important work was the Matéria médica. Físico-históricomecânica/Materia medica. Physical-mechanical history (Jacob de Castro Sarmento, 1735) where he wrote about medicines of mineral origin. Chapter VII is devoted to a detailed chemical study of mineral waters. Sarmento was the first, of the authors referred in this article, that be informed in the most recent works on this subject. He cites the books of Robert Boyle (1684-85), Martin Lister, Friedrich Hoffmann (1703), that he knew, at least through the recent English edition of Peter Shaw (1731) and even the one by Thomas Short (1734), that had just been printed. Referring directly to the book of Fonseca Henriques, Sarmento criticized those who wrote about mineral waters and just repeated popular beliefs without their own study and investigation. He described in detail the method to use various chemicals and apparatus in the study of waters and the different types of mineral waters, referring to their therapeutic properties and to various techniques used in their analysis. He also describes an analysis of the waters of New Turnbridge, done in collaboration with Shaw in 1731. The final part of the chapter is dedicated to the therapeutic properties and the method of administration of the Caldas da Rainha waters, both in the form of drink and bath. Sarmento considered these waters to be superior to the better known sulfurous waters of Europe, and accused the Portuguese physicians, particularly those at Caldas da Rainha, of being responsible for their obscurity.

Despite the importance given to the fact that the spas acquired the virtues of the subterranean metals that they passed through, the Portuguese authors of the Baroque that wrote about national waters, including those who sympathized with the adoption of chemical therapy, did not show any interest in studying its chemical contents in the laboratory, limiting themselves to conjectures over their organoleptic characteristics. Madeira Arrais, based only on its smell, introduced the idea that the water of Caldas da Rainha was constituted of tanquia, a substance obtained from orpiment (Arsenic trisulphide, $\mathrm{As}_{2} \mathrm{~S}_{3}$ ) and lime (Arrais 1642: 207). In the mid-seventeenth century there was a current opinion among physicians that the waters of Caldas da Rainha contained mercury, as deduced from the story of the Carmelite provincial that, to avoid the journey of a young nun to Caldas da Rainha, compelled her to take a bath, in her own convent, in a tub of hot water with sulfur, saltpeter and mercury, because the best physicians of Lisbon declared that the Caldas da Rainha waters virtues came just from those three substances (São Paulo 1944: 54). This presence of mercury is reaffirmed in the Pires da Silva monograph (Silva 1696). The surgeon-major António Prado Araújo (?-1691), in an information rendered to A. Limon Montero, even affirmed that, by evaporation, the waters of Caldas da Rainha left a deposit of mercury, iron, bitumen and sulfur (Carvalho 1932: 117-118). The physician of Caldas da Rainha, Belchior Ribeiro de Araújo, seems to have been the first discordant voice, when he affirmed in 1698 that in his experience, the waters showed only the existence of sulfur and niter. For him, the thesis about the presence of mercury had no serious base and the 
sulfurous bath had enough qualities to cure syphilis and other illnesses (Carvalho 1932: 121-22). Despite the opinion of this colleague, Fonseca Henriques kept repeating the current belief that the waters contained mercury (Henriques 1726: 5). This myth probably originated from the already cited passage of Madeira Arrais, where he affirmed that all mineral waters held the virtues of mercury because they have the virtues of subterranean metals and these, in the chemists' opinion, were generated by sulfur and by mercury. This line of reasoning, as Castro Sarmento pointed out in 1753, developed from a complete and inexplicable confusion between the elemental mercury of Paracelsus and metallic mercury. In spite of all, this story was still repeated in 1743 by the engineermajor Manuel da Maia (Sarmento 1753: 67 and 101).

Fonseca Henriques, despite having the fame of being "very skilled in the art of Alchemy" (Machado 1747: 148), was still ignorant in 1726 about the work Methodus examinandi aquas salubres (Halle, 1703) by the German Friedrich Hoffmann (1660-1742) concerning the analysis of mineral waters and neither him nor the other authors that spoke of the contents of Portuguese waters referred to the tests previously developed by Boyle and described in Short memoirs for the natural experimental history of mineral waters (Robert Boyle, 1684-5). Until 1753, all that was written about the contents of the Caldas da Rainha waters was based only on observation backed up by the senses. Similar conjectures were made in relation to the waters of Lafões and Monchique. Pires da Silva considered the first ones to be sulfurous, with a small portion of saltpeter. As proof, he referred to the aspect of the deposits formed around the fountains and baths and the fact that the water had a smell of gunpowder (Silva 1696: 123). António Teixeira thought that the waters of Monchique contained sulfur and some alumen. He did not undertake any analysis of the waters, confirming never to have distilled them, despite knowing that this was current practice in the study of mineral waters. On the other hand, after evaporating the water to dryness, he examined the residue through its smell, taste and color (Carvalho 1939: 38).

The absence of a true curiosity regarding chemical analysis developed naturally from the resistance taken by seventeenth and eighteenth centuries Portuguese physicians to any type of manual work, including the manipulations of the chemical laboratory, which could endanger their status of ennobling profession. This resistance, that constituted one of the greatest obstacles to the scientific and technical renovation in Portuguese Medicine, explains the fact that the first chemical analysis was conducted precisely by an emigrated physician. But Castro Sarmento also possessed another characteristic, his basic attitude was not the one of a Galenist. None of the other physicians we mentioned had any real interest in knowing the true composition of mineral waters. The conjunction of the water temperature with the easily detected presence of sulfur, granted them with hot and dry qualities strong enough to be able to conclude with assurance about their effectiveness in diseases caused by cold, phlegmatic and melancholic humors, like paralysis, convulsions, sciatica, hysterical accidents, painful legs and arms, headaches, memory loss, epilepsy, apoplexy, vertigo and many others. All the rest were unnecessary entertainments. 
Despite what he wrote in Matéria médica (1735) about the necessity of a specific chemical test, Castro Sarmento published his notes about the waters of Caldas da Rainha without having carried out any chemical analysis of them. The description of its contents, as he himself informed, had been done entirely from the use of the senses or by deductions from therapeutic effects of the waters. The identification of the presence of sulfur, a neutral saline substance and iron sulphate and his violent opposition to the possibility of the presence of mercury were not based on any laboratory operation. On the other hand, Sarmento published a detailed description of the analytical methods which could be followed by spa physicians. Only in 1743 did Sarmento carry out its chemical analysis, from the bottles which had been sent to him in London. This work was preceded by another examination, more methodical than the previous ones but far from what one could consider as thoroughly chemical study, carried out in 1742 by the brigadier Manuel da Maia (ca. 1680-1768). The exam by Maia is described in "Memórias para o Sistema de agoas dos banhos das Caldas da Rainha, principiadas no anno de 1742”. This manuscript was, by order of the King, forwarded to Castro Sarmento, who published it in 1753 (Sarmento 1753: 44-80). Despite claiming to have followed the steps taught by Friedrich Hoffmann, the observations of Maia are very primitive. The experiments he described were very few and elementary. He claims to have used some chemicals but he was unable to draw any conclusion from their use. In spite of all the limitations, the tests carried out were sufficient to convince Maia of the absence of mercury, nevertheless he still suggested the possibility of its existence in quantities so small that they were difficult to detect. The qualitative chemical analysis of the waters of Caldas da Rainha carried out by Sarmento in 1743-44 were in fact much more comprehensive. They were based on the use of the same reagents which use he suggested in 1735. Sarmento also carried out the distillation and evaporation of the waters, as well as the recrystallization and calcination of the residue and its weighing and microscopic observation. He also asked John Fothergill (1712-1780) to accomplish an independent test and he performed a comparative analysis with the waters of Bath. Castro Sarmento was the first to start an abundant literature concerning mineral waters, that flourished during the second half of the century ${ }^{2}$ and culminated in 1810 with the major synthesis Instruções e cautelas práticas sobre a natureza, diferentes espécies em geral, e uso legítimo das águas minerais/Instructions and precautionary practices about the nature, different species in general and legitimate use of mineral waters (Francisco Tavares, 1810) (Guimarães 1946/47: 19-70). Half of these works were dedicated to the Caldas da Rainha waters. The Lisbon Academy of Sciences encouraged the research on Portuguese hydrological resources and various monographs were presented to the Academy by Nunes Gago and other authors since $1786^{3}$. The growing interest in the therapeutical use of mineral waters went along with the concern about its legitimization, through clinical observation but also through the chemical analysis of its mineral contents. Since the Apendix (Jacob de Castro Sarmento, 1753), the communication of analytical results became a common practice in most of the monographs about mineral waters ${ }^{4}$. 


\section{CONCLUSIONS}

The use of medicinal waters and spas in Portugal was the subject of a growing interest throughout the second half of the 17th century and the first half of the 18th century. This interest developed as a result of the sponsorship and example of the royal family and court, focusing mainly on tCaldas da Rainha. Almost all the monarchs of the Bragança dynasty frequented these spas since 1640, but it was with D. João $\mathrm{V}$ that they reached the maximum of their fame and development.

The demand for Caldas da Rainha was a natural consequence of the greater accessibility and resources existing there, far superior to those of other spas, as well as the fame regarding the immunity of this place to the waves of pestilence that plagued the country since the sixteenth century. At the turn of the 17th to the 18th centuries, only Caldas da Rainha had adequate personnel and facilities to receive a significant number of patients. The Lafões baths followed, and at a much greater distance, those of Monchique. The difficulty of finding accommodation or food was one of the main fears of patients and caused the low frequency of many hot springs. Caldas da Rainha was the only spa with large facilities, with different wards for various social groups, including rooms for members of the nobility.

In spite of these possibilities, the eminently charitable nature of its activity and the tight control of the administration by members of the clergy or the nobility seems to have been a brake on the development of Portuguese baths. The patients who came to Caldas da Rainha were attracted by the fame of the waters and by the fact that the King and the members of the Royal Family were attracted by them, but when they arrived they were faced with several difficulties. While members of the nobility could be placed in private quarters, paying only for food and health care, members of the middle classes, who could not mix with the poor in the wards, had to spend much larger sums, lodging outside the hospital. Patients in the mechanical crafts and trades had no alternative but to sleep and take baths in the midst of a multitude of wretches. Certainly this situation, although favorable to the members of the clergy and the nobility, did not encourage the frequency of caldas by the remaining strata of the population. The atmosphere and customs of Caldas da Rainha were also not conducive to a pleasant stay. Not only the religious, but also the secular patients admitted to the hospital were subject to the most rigorous closure. Amusements were almost non-existent and contradicted by the spa administration.

Literature on mineral waters was conditioned by the functioning and evolution of the baths. In spite of the existence of an important thermal institution in the Caldas da Rainha since the sixteenth century, studies on Portuguese mineral waters during this period were not only scarce but also too dependent on the King's occasional interest, rather than stemming from its own vitality or general curiosity about hydrotherapy. The interest of Portuguese physicians in mineral waters took a similar path to that of the adoption of chemical medicines: the process of popularizing the baths acquired a new impetus during the second half of the seventeenth century and was consolidated at the 
beginning of the following. Likewise, many of the authors who played a prominent role in the diffusion of hydrotherapy also stood out as supporters of chemical therapy. The use of mineral waters occupies a particular place within the dominant eclectic attitude among the Portuguese physicians of the Baroque, allowing a total agreement between traditionalistic Galenists and sympathizers, more or less ambiguous and little informed, of the chemical doctrines. Despite the fact that they shared an interest both on chemistry and mineral waters, the Portuguese authors of the Baroque who wrote about hydrotherapy showed no concern to study the waters chemical composition in the laboratory, limiting themselves to conjecture about their organoleptic characters.

The absence of any real concern in carrying out chemical analyzes was naturally a result of the resistance of Portuguese doctors of the seventeenth and eighteenth centuries to any kind of manual labor, including that of the chemical laboratory, which might jeopardize their status as a profession. This resistance, which constituted one of the greatest obstacles to scientific and technical renewal in Portuguese Medicine, explains the fact that the first chemical analysis was carried out precisely by an emigrant physician. But Castro Sarmento had another fundamental characteristic. His basic attitude was no longer that of a Galenist. None of the other physicians had any real interest in knowing the true composition of mineral waters. The combination of water temperature with the presence of sulfur, which was easily detectable, gave them the warm and dry quality sufficient for them, as Galenists, to safely conclude their efficacy in diseases caused by cold, phlegmatic and melancholic substances and humors, such as Paralysis, convulsion, sciatica, hysterical accidents, leg and arm pains, headaches, memory deficits, epilepsy, stroke, vertigo and many others. All the rest were unnecessary preciosities.

Castro Sarmento inaugurated an abundant literature on mineral waters in the second half of the century, half of which dedicated to Caldas da Rainha, culminating in 1810 with the synthesis of Francisco Tavares, Instruções e cautelas práticas sobre a natureza, diferentes espécies em geral, e uso legítimo das águas minerais. The Lisbon Academy of Sciences encouraged the writing of memoirs concerning mineral waters, written by Nunes Gago and others since 1786. The interest in the use of mineral waters in therapy was accompanied by the study of their chemical composition. Since the Apendix of Castro Sarmento (1753), the inclusion of analytical results became a current practice in most of the texts on mineral waters. 


\section{ENDNOTES}

1 "I will do what you advise me because in this hospital I am at your obedience".

2 That includes texts by A. M. Beleza about Caldas do Gerez (1763), A. F. Silva about a ferrous water from Vila Nova de Gaia (1764), J. M. Cunha Pessoa (1773), João Nunes Gago (1779), J. I. Seixas Brandão (1781), Francisco Tavares (1791) and William Withering (1795), all about Caldas da Rainha; F.A. Beja e Noronha about the waters of Fala (1789), the apothecary Friar Cristóvão dos Reis in the Reflexões experimentais metódico-botânicas (1789), where he studied various medicinal waters from the north of the country, F. Valois e Silva about the mineral waters of Furnas da Ilha de S. Miguel (1791), C.A. Oliveira e Silva about the Ferrous waters of Constança (1799) (Acciaiuoli 1950b).

3 Dealing with the waters of Serra da Graça, Chaves, Alferce - Monchique, Fontaínhas - Tavira, Monchique e Venda Seca, among others. W. Withring's work was also published by the Academy.

4 Namely in the ones by A. F. da Silva, J. M. Cunha Pessoa, J. Nunes Gago, J. I.Seixas Brandão, F. A. Beja e Noronha and mainly in W. Withering's.

\section{REFERENCES}

Acciaiuoli, L. (1944), Águas de Portugal. Minerais e de mesa. História e bibliografia, 6 vols., Lisboa: DGMSG.

_ (1950a), Bibliografia hidrológica do Império português, 2 vols., Lisboa: DGMSG.

_ (1950b), "História da Química na Hidrologia Portuguesa”, Memórias da Academia de Ciências. Classe de Ciencias, 5, pp. 215-267.

Arrais, Duarte Madeira (1642), Método de conhecer e curar o morbo gálico, Lisboa.

Brockliss, L. W. B. (1990), "The development of the spa in seventeenth-century France”, in R. Porter, The medical history of waters and spas, London: Wellcome Institute for the History of Medicine, pp. 23-47.

Carvalho, A. Silva (1930), Subsídios para a História das Caldas de Monchique, in "Jornal da Sociedade das Ciências Médicas de Lisboa”, Lisboa.

_ (1932), Memórias das Caldas da Rainha. 1484-1884, Lisboa. (1939), Memórias das Caldas de Monchique, Lisboa.

(1941), Memórias das Caldas do Gerez, in “Jornal da Sociedade das Ciências Médicas de Lisboa”, Lisboa, Imprensa Médica.

Coley, N. G., (1979) , "Cures without care: chemical physicians and mineral waters in seventh-century England”, Medical History, 23, pp. 191-214,

(1982), "Physicians and the chemical analysis of mineral waters in eighteenth-century England", Medical History, 26, pp. 123-144

(1990), "Physicians, chemists and the analysis of mineral waters: 'The most difficult part of chemistry'،, in R.

Porter, The medical history of waters and spas, London: WIHM, pp. 56-66.

Correia, F. Silva (1935), Alguns aspectos da Hidrologia médica portuguesa, in “Clínica, Higiene e Hidrologia”, vol. 8, Lisboa.

(1957), Portugal pioneiro da assistência termal in “Clínica, Higiene e Hidrologia”, Lisboa.

Dias, J. P. Sousa (2007), Droguistas, boticários e segredistas. Ciência e Sociedade na Produção de Medicamentos na Lisboa de Setecentos. Lisboa, FCG/FCT.

Guimarães, F.A. da Cunha (1946/47), “Francisco Tavares. Hidrologista”, Arquivos do Instituto de Farmacologia e Terapêutica Experimental 9, pp. 19-70.

Henriques, Francisco da Fonseca (1726), Aquilegio medicinal, em que se dá notícia das águas de Caldas, de Fontes, Rios, Poços, Lagoas, e Cisternas, do Reino de Portugal, e dos Algarves, que ou pelas virtudes medicinais, que tem, ou por outra alguma singularidade, são dignas de particular memória, Lisboa, Oficina da Música.

Lemos, Maximiano (1991), História da Medicina em Portugal. Doutrinas e instituições, 2nd ed., 2 vols., Lisboa: Publ. D. Quixote/Ordem dos Médicos.

Machado, Diogo Barbosa (1747), Biblioteca Lusitana, vol. 2, Lisboa. 
São Paulo, Jorge de (1928), História da Rainha D. Leonor e da fundação do Hospital das Caldas, ed. F. Silva Correia, Lisboa, ENP.

(1944), A Medicina termal portuguesa na Época da restauração, ed. F. Silva Correia, Lisboa, Imprensa Médica. (1959), Antiguidades das Caldas da Rainha e do tempo da Rainha D. Leonor, ed. F. Silva Correia, Caldas da Rainha.

(1967-1968), O Hospital das Caldas da Rainha até ao ano 1656, 3 vols., Lisboa: Academia das Ciências.

Sarmento, Jacob Castro (1753), Apêndice ao que se acha escrito na Matéria Médica sobre a natureza, contentos, efeitos e uso prático, em forma de bebida, e banhos, das águas das Caldas da Rainha, London.

Semedo, João Curvo (1687), Polianteia Medicinal, Lisboa.

Silva, A. Pires da (1696), Cronografia Medicinal das Caldas de Alafões, Lisboa, Oficina de Miguel Deslandes.

\section{Short biography}

José Pedro Sousa Dias is currently the Director of the National Museum of Natural History and Science / Museums of the University of Lisbon. He is Associate Professor at the Faculty of Pharmacy of the University of Lisbon, where he teaches History of Pharmacy and Therapeutics. He is a member of the research group Science: Studies in History and Philosophy of Scientific Culture (CEHFCi) of the Institute of Contemporary History (IHC). Its current research interests are the contemporary history of the biomedical sciences in Portugal, the scientific and social aspects of the history of the medicine (17th and 18th centuries) and the history of medicine and pharmacy in Portuguese expansion and colonization (16th to 19th centuries). He was Pro-Rector of the University of Lisbon (05/2006-05/2009 and 09/2010-12/2011). Sub-director of the Faculty of Pharmacy (11/2009-08/2010). From 2006 to 2011, he presided the Executive Committee of the Commemorations of the Centenary of the University of Lisbon. President of the Board of Directors of the Museums of the University of Lisbon (06/2012-02/2014) and its Director since February 2014. Recent publications: Sousa Dias, J. P. "'Meninas prendadas' e 'Fêmeas ambiciosas': Portugal, Cajal e o papel da mulher na investigação biológica na primeira metade do século XX". in M. C. Pimentel e P. F. Alberto (eds.). Vir bonus peritissimus aeque. Estudos de homenagem a Arnaldo do Espírito Santo. Lisboa: Centro de Estudos Clássicos, 2013. pp. 989-1008; Sousa Dias, J. P. "Medicina, ciência e laboratório". in Sérgio Campos Matos e Jorge Ramos do Ó (coord.). A Universidade de Lisboa nos Séculos XIX e XX. Lisboa: Tinta-da-China, 2013. Vol. II. pp. 651-717; Sousa Dias, J. P. "A vida para além do Estado: Financiamento privado da investigação biomédica em Portugal (1926-1936)". in A. J. S. Fitas et al (eds.). A Junta de Educação Nacional e a investigação científica em Portugal no período entre guerras. Lisboa: Caleidoscópio, 2013. pp. 113-135; Sousa Dias, J. P. A Água de Inglaterra. Paludismo e Terapêutica em Portugal no século XVIII. Lisboa: Caleidoscópio, 2012.

Contact information:

Email: jpsdias@museus.ulisboa.pt

Tel. 210443457 